\title{
Construction site design planning using 4D BIM modeling
}

\author{
Planejamento para projeto de canteiro de obra com uso de \\ modelagem BIM 4D
}

\author{
Caroline Wilsek Caldart ${ }^{1}$, Sérgio Scheer ${ }^{1}$ \\ ${ }^{1}$ Universidade Federal do Paraná - UFPR, Programa de Pós-graduação em Engenharia de Construção Civil - \\ PPGECC, Curitiba, PR, Brasil. E-mail: carolinecaldart@yahoo.com.br; sergioscheer@gmail.com.br
}

How to cite: Caldart, C. W., \& Scheer, S. (2022). Construction site design planning using 4D BIM modeling. Gestão \& Produção, 29, e5312. https://doi.org/101590/1806-9649-2022v29e5312

\begin{abstract}
Adequate construction site planning provides productivity and safety gains and reduces material transportation costs. However, as they take a dynamic structure, the construction site layout planning is quite often complex and inefficient. 4D BIM modeling helps to visualize the spatial layout of objects on the construction site throughout the project establishing their positioning during a specific time, thus providing better results for the physical use of space. By using the Design Science Research method, this article aims to establish a process using 4D BIM modeling to implement the planning and management of construction sites taking into account their key characteristic, dynamism.
\end{abstract}

Keywords: Construction site planning; Dynamic construction site; 4D BIM.

Resumo: Um planejamento adequado de canteiro proporciona ganhos com produtividade e segurança e reduz custos com transporte de materiais. No entanto, por assumirem estruturas dinâmicas muitas vezes o planejamento do layout do canteiro de obra torna-se uma tarefa complexa e ineficiente. A utilização da modelagem BIM 4D auxilia na visualização do arranjo espacial dos objetos no canteiro ao longo da evolução do empreendimento, de forma a estabelecer as suas alocações em um período de tempo específico, proporcionando melhores resultados quanto ao aproveitamento físico do espaço. Utilizando o método Design Science Research este artigo tem como principal contribuição definir um processo utilizando a modelagem BIM 4D para implementar o planejamento e o gerenciamento de canteiros levando em consideração a característica fundamental de canteiros de obras que é o dinamismo.

Palavras-chave: Planejamento de canteiro de obras; Canteiros dinâmicos; BIM 4D.

\section{Introduction}

The construction site layout planning aims to reduce material transportation costs and ensure gains in safety and productivity, thus, its development is vital for the efficiency and quality of construction work (Cheng \& Chang, 2019; Kumar \& Cheng, 2015; El-Rayes \& Khalafallah, 2005; Yeh, 1995). The construction site must support construction operations (Gehbauer, 2002, p. 63) and production resources (labor,

Received Jan. 22, 2020 - Accepted Mar. 13, 2021

Financial support: None.

This is an Open Access article distributed under the terms of the Creative Commons Attribution License, which permits unrestricted use, distribution, and reproduction in any medium, provided the original work is properly cited. 
materials and equipment) must be organized and distributed to support and carry out the work on-site (Maia \& Souza, 2003).

Measuring the benefits provided by adequate construction site planning is a difficult task, but the inconveniences caused by its absence are easily noticed (Tommelein et al., 1992; Kumar, 2015).

Saurin \& Formoso (2000) studied the usual layout planning and site logistics practices by analyzing 40 construction sites from 28 construction companies in the greater Porto AlegreRS, Brazil. As a result, it was observed that the construction sites had no formal planning. The spatial materials layout was established at the same time as the work was performed on-site, with perceptions and planning patterns based on professional experiences.

For Martins \& Laugeni (2005), to establish the construction site layout, a plan involving the whole must be done first and then by the parts, e.g. ideal planning followed by the practical one. The layout starts as an overview, later detailed. After its implementation, such planning should be reformulated whenever necessary. Different alternatives should be generated and evaluated until a more adequate decision is reached. The proposed alternatives must be visualized, the physical and scale representation of the material flow allows an understanding of the traffic to be presented by the layout.

Zouein \& Tommelein (1999) define the layouts for construction sites in two categories:

(1) Static models: assume that the assembling of installations occurs at the beginning of the construction work, remaining unchanged during the entire construction process, ignoring the possibility of reusing spaces to accommodate different resources at different stages of the work;

(2) Dynamic models: consider the actual time duration required for each equipment or installation. Objects such as containers or equipment take a specific area that tends to be on a permanent basis. However, palletized or mixing resources (e.g. bricks or gravel) are smaller, not having a permanent size, which might be distributed around the site or positioned anywhere that has their sizes, such locations may vary over time, during the construction development and consumption of materials.

Construction sites are dynamic structures that change as the project develops (Zolfagharian \& Irizarry, 2014). For this reason, their planning must consider this structure. The space allocated to a specific object is transferred to another one at different periods of the schedule, providing better results as to the use of available space (Sadeghpour \& Andayesh, 2015). The positioning of resources, both in confined construction sites and in large areas, is not a trivial issue. Pre-determining the appropriate location of material, meeting a series of constraints, is hard to solve given the endless possibilities (Li \& Love, 1998).

Good construction site layout projects seek to meet multiple goals, which are often conflicting. Material transportation time reduction, for instance, could increase congestion or positioning most objects closer to one another could improve workflow but might cause accidents. Therefore, the aims to be met need to be defined in terms of priority, (sadly there is no consensus on the method to be used for such task) (Andayesh \& Sadeghpour, 2013; Sadeghpour \& Andayesh, 2015).

To establish models that are more coherent with the actual construction sites situations and due to their complexity and a great number of variables in the construction site planning process, the use of software has been adopted since the late 1980s (Sadeghpour et al., 2004 apud Sadeghpour \& Andayesh, 2015), and more recently, the Building Information Modeling (BIM) has proven to be an efficient process.

The 4D BIM model is a 3D model combined with the time factor. The tasks that make up the schedule structure and analytical design structure (WBS - Work Breakdown Structure) are linked to components or parts of the 3D model. This allows the visualising of the construction 
work sequence, consequently facilitating the understanding of the production procedure by those involved in the process management (Kymmel, 2008).

To analyze construction site planning dynamic models, BIM models are relevant sources of information and are used to facilitate the construction site layouts planning with various applications such as geospatial analysis, construction site elements behavior simulation and construction supply chain visual monitoring improvement. These models, in conjunction with the construction site schedule, establish the basis for quantitative sizing of temporary installations at different stages of construction. (Kumar \& Cheng, 2015; Marzouk \& Abubakr, 2016). Yu et al. (2016) state that THE 4D BIM models application for construction sites ensures a timely visualization of the schedule stages as a whole, allowing for an analysis that contributes to better supply chain solutions.

The BIM model is suitable to meet the activities control, since it could provide information and support as to work guidelines and planning processes, stimulating more accurate planning for the site physical space use. Also, it presents progress regarding risk and communication management, since it allows sending adequate information to those involved in the process and it is also able to offer strategic simulations analysis support (Sulankivi et al., 2009) since it provides a dynamic and clear workplace view (Zolfagharian \& Irizarry, 2014).

For Bataglin et al. (2018), the use of 4D BIM models on construction sites is not only intended for visualization purposes but also to provide integration and sharing of relevant information, contributing to logistics processes standardization. The availability of information and the opportunity for quick changes to plans assisted by 4D BIM modeling makes the logistics management decision-making process more effective. Whitlock et al. (2018) also mentioned benefits such as better information logistics understanding, construction site safety issues support and layout planning efficiency (avoiding time and space conflicts).

BIM-based construction site planning is a method for managing, connecting and using information, providing different viewpoints required for the same plan, where spatial information on objects, physical space, details, specifications, equipment and materials characteristics may be used for layouts simulations and decision-making support. The 4D BIM modeling main advantage is the development potential of a dynamic construction site planning integrated with production planning (Sulankivi et al., 2009).

This study aims to report the 4D BIM modeling use for construction sites dynamic layout planning, creating an adequate and feasible process. It is clear that the lack of construction sites management and planning results in losses that are often hard to measure. Even so, the absence of minimum requirements to manage these possible expenditures is alarming. Therefore, defining processes and implementing the construction sites management and planning are not trivial or frivolous tasks, but ought to be considered essential for the success of the enterprise.

\section{Research methods}

As a result of the above findings, the research was developed using the Design Science Research approach, which produces a feasible artifact model, aimed at developing solutions to important and relevant problems for organizations (Hevner et al., 2004) and change observed conditions to better or desirable states. In this context, an artifact is a product developed by man or artificial objects that may be characterized in terms of goals, functions and adaptations, i.e. the organization of internal environment components to achieve goals in a given external environment (Dresch et al., 2015; Simon, 1996). 
To legitimize the developed artifact, the process implementation within a construction work in progress was looked at, with issues such as value for money and the environmental/contextual characteristics to which it was inserted.

Based on the sequence of stages for the research development proposed by Dresch et al. (2015), the study was split into eight sequential phases, as seen in Figure 1.

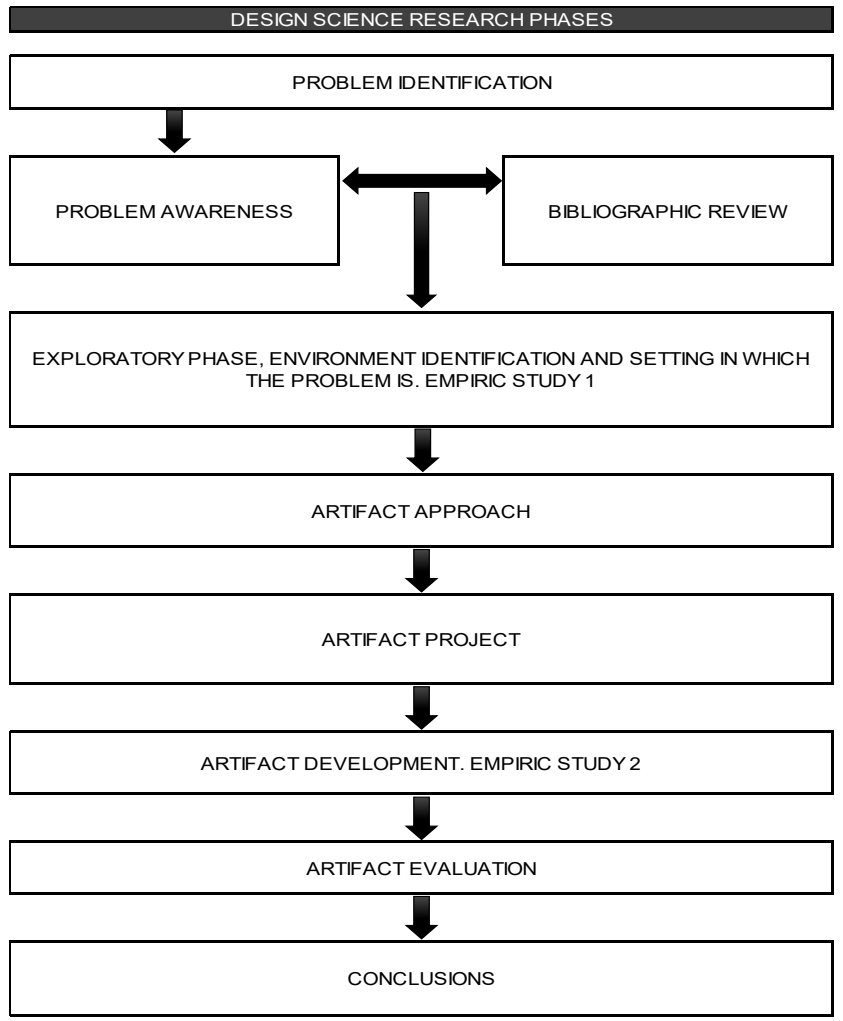

Figure 1. Proposed stages for Design Science Research performance.

\subsection{Problem identification, awareness and bibliographic review}

(a) Problem identification: Evidence of disregard in the construction site as to their planning and management, as presented by Saurin \& Formoso (2000);

(b) Problem awareness: Lack of construction sites planning and management causes productivity losses, increased transportation costs and consents to an accidentprone environment. The construction site purpose is to support the enterprise execution, so it is essentially dynamic and must adapt to the characteristics of the construction work throughout its development. Hence, the development of a construction site planning and management become a complex but essential task;

(c) Bibliographical Review: In this phase of the research, the main published contributions on the following topics were sought: construction site planning, material flow at the construction sites, supply chain management, planning models for construction sites and 4D modeling for construction site planning.

From the information taken for construction sites planning, the main goals and planning relevance were identified and the dynamic models were defined. For 
previously established findings on the materials flow, matters regarding ordering, storage, receiving and application of input within the construction work physical space were identified, as well as the supply chain, with the subject characterized within the construction sector, for establishing its specificities.

In the construction sites models planning, the main studies developed for the site layouts elaboration were researched, characterizing the approaches adopted and their components. Figure 2 presents the main contributions found.

\begin{tabular}{|c|c|c|c|}
\hline Zouein \& Tommelein & Elbeltagi et al. & Park et al. & Su et al. \\
\hline $\begin{array}{l}\text { Developed a graphics tool } \\
\text { called MovePlan - It uses the } \\
\text { correlation between activities } \\
\text { entered creating optimized } \\
\text { construction site layouts. }\end{array}$ & $\begin{array}{l}\text { Developed a dynamic } \\
\text { construction site planning } \\
\text { tool using the built areas of a } \\
\text { building to store provisional } \\
\text { installations and reduce site } \\
\text { congestion. }\end{array}$ & $\begin{array}{l}\text { Developed a process } \\
\text { methodology to optimize } \\
\text { the internal storage areas } \\
\text { for construction materials. }\end{array}$ & $\begin{array}{l}\text { Developed an evaluation } \\
\text { tool based on a } \\
\text { geographical information } \\
\text { system (GIS) for materials } \\
\text { positioning. }\end{array}$ \\
\hline
\end{tabular}

\begin{tabular}{|c|c|c|c|}
\hline Said \& El-Rayes & Said \& El-Rayes & Yu et al. & Cheng \& Chang \\
\hline $\begin{array}{l}\text { Proposed logistic planning for } \\
\text { construction works at } \\
\text { congested construction sites }\end{array}$ & $\begin{array}{l}\text { Developed a multi-objective } \\
\text { automated construction } \\
\text { logistic optimization system } \\
\text { using BIM modeling and } \\
\text { schedule data to maximise } \\
\text { internal storage space usage } \\
\text { in a building. }\end{array}$ & $\begin{array}{l}\text { Developed a BIM-based } \\
\text { practical and informative } \\
\text { model for supply of } \\
\text { materials in the } \\
\text { construction site. It links } \\
\text { the requests for the } \\
\text { number of materials with } \\
\text { the construction site } \\
\text { dynamic models, creating } \\
\text { construction site layout } \\
\text { images adjusted to the } \\
\text { supply chain planning. }\end{array}$ & $\begin{array}{l}\text { Matched the use of BIM and } \\
\text { "symbiotic organisms } \\
\text { search" algorithm to } \\
\text { develop the construction } \\
\text { site's materials layout } \\
\text { dynamic planning. They } \\
\text { used 4D BIM combined with } \\
\text { a quantitative analysis of } \\
\text { construction materials }\end{array}$ \\
\hline
\end{tabular}

Figure 2. Reference of studies for construction site layouts development.

More specifically, 4D modeling contributions on construction site planning were researched. 4D models application in the civil construction sector was contextualized, and the advantages of method applying within the construction site were pointed out.

\subsection{Exploratory phase: environment identification and problem configuration}

In this research phase, the passive observation of construction site planning process for data collection was used. The construction work is a 14-storey tower hotel centrally located in São Paulo-Brazil in an area with heavy traffic of vehicles and pedestrians. The construction site has a restricted and confined space and difficult access, as well as limitations for vehicle maneuvers.

The construction company hired a specialist company to develop a construction site layout planning study to solve the logistics for inserting objects within a reduced physical space and optimize production during the construction work stages. The planning was divided into three stages: (1) Attack plan; (2) Macro transport logistics (3) Construction site project.

Souza (2000) defined that for a construction site's concept and implementation that has a construction project and available time for it, must first establish an attack plan followed by the physical schedule. When the construction site location is determined, the information needed to establish the process to be used is accomplished. The 
demand for materials, labor and equipment is quantified and thus determines the space required for the construction site. The information set contributes to the proposition of one or more options for the construction site. Each proposal is evaluated until its approval for implementation.

At the attack plan stage, the activities sequence and deadlines are defined. The strategic schedule lists the activities that will be executed in each month, taking into account the specificities involving the external environment and the construction site objects disposition and necessity as the work develops. This stage aims to foresee the logistic organization of materials and equipment for task performance as well as the construction site objects distribution to efficiently assist the work development. For each logistics material adaptation, spatial layouts and modification in the material logistics, a construction site layout analysis is done and a $2 \mathrm{D}$ study is developed showing its configuration.

The macro logistics and transportation stage analyzes the materials' internal transportation and their inbound delivery and storage logistics. For the materials vertical transportation inside the construction site, the use of a rack elevator was chosen taking into account the number of cabins needed, the load capacity of the equipment, using time, its positioning on-site and the need of auxiliary transportation equipment. Considerations were also made on the types of material unloading equipment since the use of some equipment become unfeasible due to the construction site physical characteristics, so it is necessary to determine in advance the suitable equipment for the main inputs inbound delivery and storage in the construction site.

The planning last stage (site design) refers to identifying temporary constructions such as communal areas and allocating of storage material at different construction work phases. For establishing communal areas facilities, the work schedule was divided into three stages, proposing a structuring of these facilities for each stage. A similar process was applied to determine material storage positioning, however, the schedule was divided into five stages, establishing the structures layout positioning on each stage.

For planning and monitoring the construction work development, the construction company hired a BIM-technology-specialist company to develop the 4D BIM and 5D BIM models. The 3D models were developed using Autodesk Revit software and their integration with the schedule (elaborated on Microsoft Project software) was done by Navisworks software.

The specialist company elaborated the 3D models of the architectural and complementary projects based on the $2 \mathrm{D}$ format projects supplied by the construction company, and thus interferences and incompatibilities were verified to then, elaborate an executable model that would better serve the production within the construction work context.

The 4D BIM model aimed to analyze and validate the construction work planning, verifying possible inconsistencies and incompatibilities.

At this stage, data such as expected deadlines, the sequence of activities, definition of critical activities and definitions of the equipment, working teams and their hiring format were collected. Documents such as site logistics studies and architectural projects were obtained. The main topics for the site logistics study development could be analyzed, as well as the observations for determining materials storage, equipment and machinery to be used, construction work execution strategy, communal areas implementation and transportation logistics. Thus, the to-be-implemented site planning process was identified and characterized to then, structure the proposition of a new optimized process that may be replicated in different construction work. 


\subsection{Artifact approach}

Based on the findings established in the previous stage, adaptations and improvements in the process were analyzed and a new process was proposed for the construction site layout planning considering its dynamic aspect.

This research stage is essentially creative, aiming to propose useful realistic situations. Thus, the artifact's proposition essential premises are fundamental to the project basis. Considering the analyses and data obtained from the previous stages, four main criteria for adequate construction site planning were listed:

1. In the continuous construction site approach use, objects positioning may be represented in any physical space, not limited by generalizations or graphic simplifications, thus being the situation more realistic;

2. It is important that the contours and edges of all objects and installations are represented in the project in a realistic format and that their mobility is similar to their behavior;

3. It is essential that for time calculation, a dynamic construction site layout is considered, establishing the residence time for each object on the site;

4. The artifact focuses on productivity improvement, taking into account safety and accessibility obtained by analysing the arranged objects relation.

\subsection{Artifact project}

After artifact proposition, the project is formalized for its development and the procedures and tools to be used are clarified, as well as its evaluation type.

The proposed findings were implemented in a new enterprise to verify the model's performance in a different environment. The artifact project was structured as presented in Figure 3.

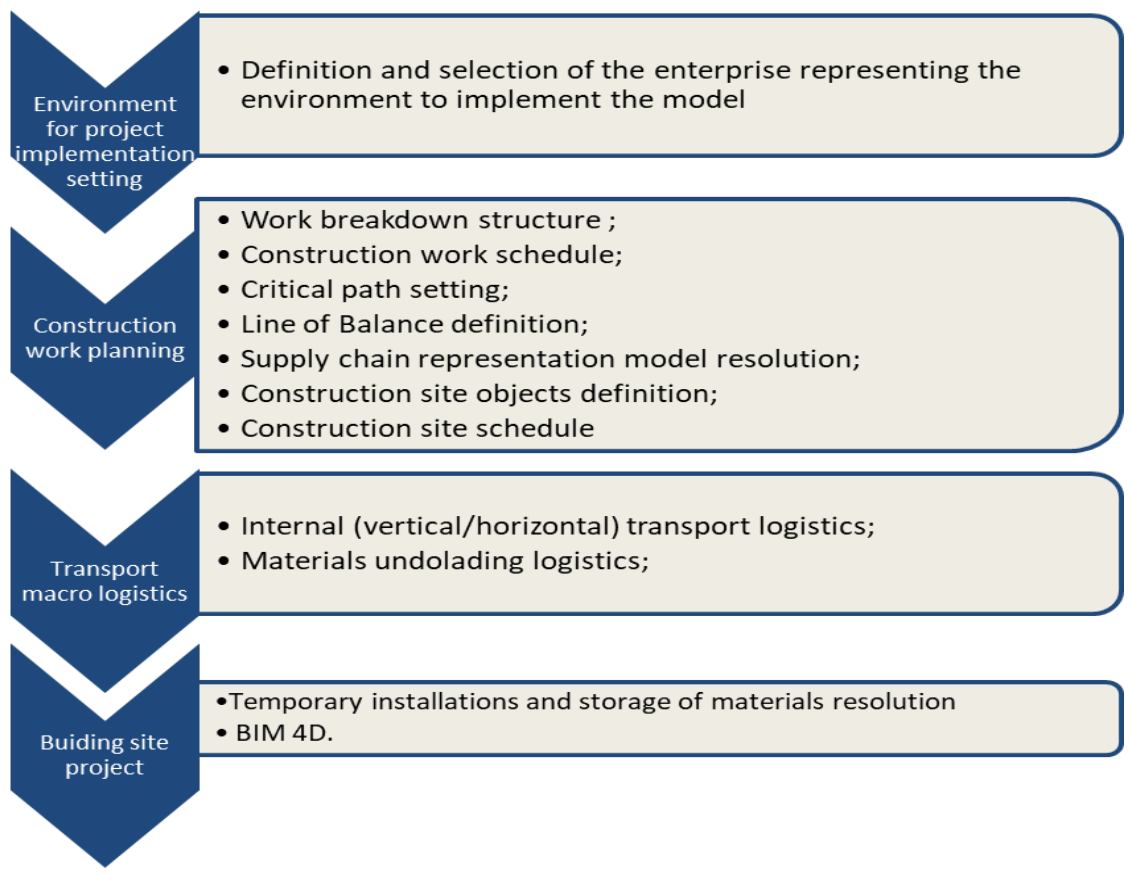

Figure 3. Artifact project framework. 


\subsection{Artifact development}

At this stage, a nine-block welfare housing development with 144 apartments built in structural masonry located in the municipality of São José dos Pinhais, in the greater Curitiba-PR, Brazil, was selected. The researcher, as the civil engineer and works manager, had full access to the enterprise to apply the method and develop the construction site 4D BIM model.

For the selected enterprise, executable construction work analyses were developed. The MS Project software was used to structure the project.

The project was initially structured in four main groups: preliminary services, infrastructure, housing and communal equipment. The tasks were then subdivided into sub-steps for control and quantification. The Work Breakdown Structure (WBS) was the basis for determining the schedule, budget, team quantification, and critical path definition.

The WBS aims to separate the activities that define the project operation stages into controlled subgroups. The four groups in which the project was structured (preliminary services, infrastructure, housing, and communal facilities) were divided into other groups and subsequently subdivided into subgroups that define the activities to be controlled and quantified. Figure 4 presents the foundation item, belonging to the housing group, subdivided into its activities.

\begin{tabular}{|c|c|}
\hline Item & Task name \\
\hline 3.1 .1 & Foundation \\
\hline 3.1.1.1 & Plot compaction \\
\hline 3.1.1.2 & Sub-base compaction \\
\hline 3.1.1.3 & Template \\
\hline 3.1.1.4 & Hydrosanitary facilities \\
\hline 3.1.1.5 & Form assembly \\
\hline 3.1.1.6 & Framing \\
\hline 3.1.1.7 & Electrical and telphone piping \\
\hline 3.1.1.8 & Concrete work \\
\hline 3.1.1.8.1 & Sill plate concrete \\
\hline 3.1.1.8.2 & Floor finish \\
\hline 3.1.1.8.3 & Subfloor \\
\hline 3.1.1.9 & Foundation forms stripping \\
\hline
\end{tabular}

Figure 4. Housing group foundation structuring into subgroups to be controlled and quantified.

With the WBS definition, the work schedule was developed. For that, strategic planning was initially established, in which a scope is defined with the enterprise goals to be achieved at a specific time-interval to establish broadly the main executable activities progress. Such strategic planning was determined by the Gantt chart, seen in Figure 5. 


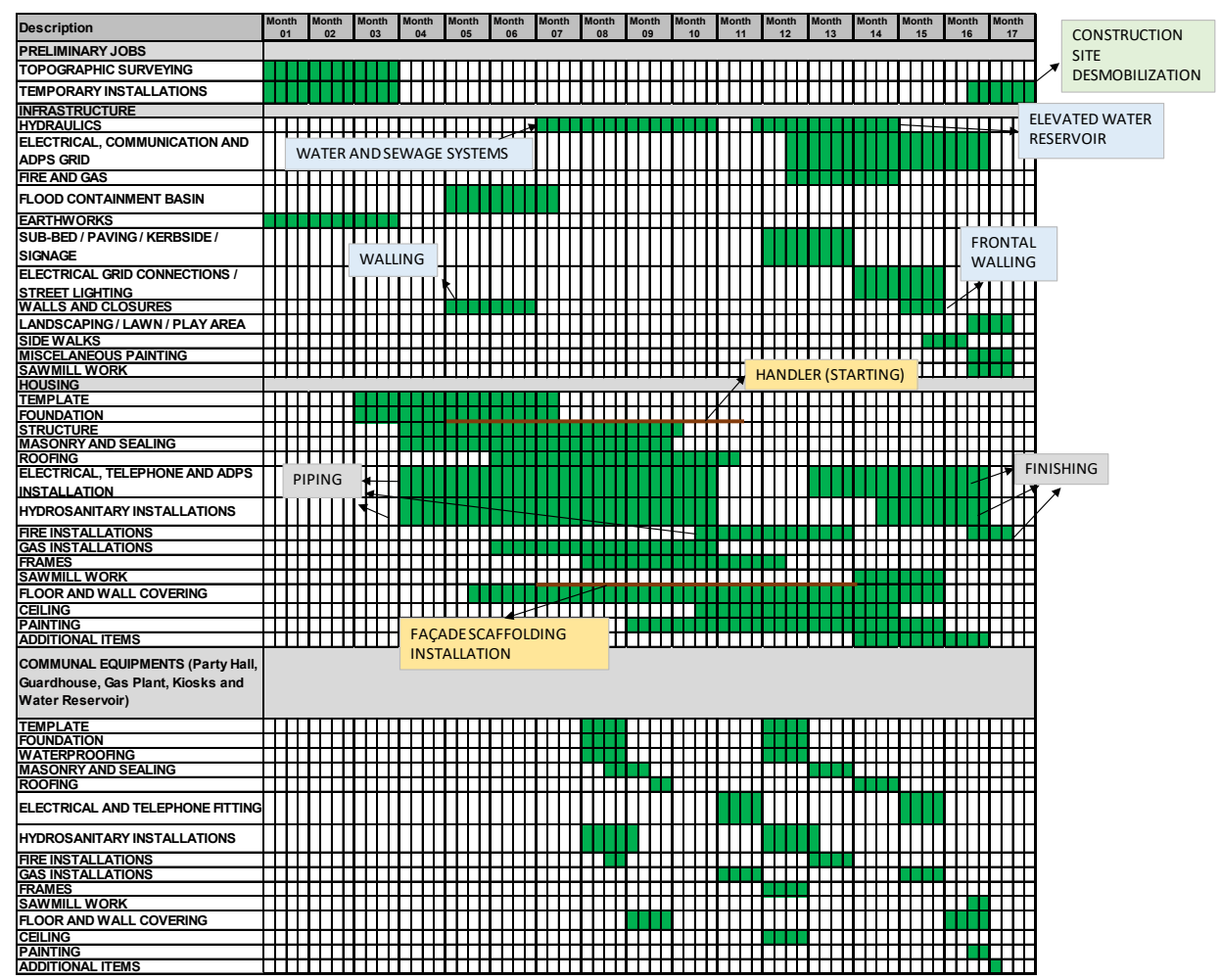

Figure 5. Gantt chart - Executable schedules for deadlines evaluation.

The Gantt chart evaluates and revises the estimated deadlines of the main activities, defining an overall time frame and resources needed for the entire project for the basis of a long term executable schedule development.

MS-Project software was used for the long-term executable schedule development. For each subgroup determined by WBS, the execution period was established based on the construction company's internal productivity data and the sequential interdependence of each subgroup was established. The construction work starting and finishing dates were determined as well as the predecessor and successor activities interdependence. The apartment blocks construction was configured as a first model repetition. Despite having two types of apartment blocks, the executable deadlines were equally defined, since their differences were not significant. Once the executable sequence of the first apartment block was defined, the others followed suit.

Having defined the schedule, the model unit network diagram was elaborated. The network allowed an activities graphical view, their critical path and their interrelations. A network was created identifying the activities and correlating them with each other. After that, their durations were included and the earliest starting and earliest finishing dates for each activity were calculated, allowing it for the project duration estimate. 129 days were determined for the studied project, which refers to the time frame needed for an apartment block construction. Then, the starting and finishing dates were determined to establish a critical path.

Once the executable sequence and the critical path for work progress were defined, the enterprise's critical path activities line of balance (LOB) was determined (Figure 6). 


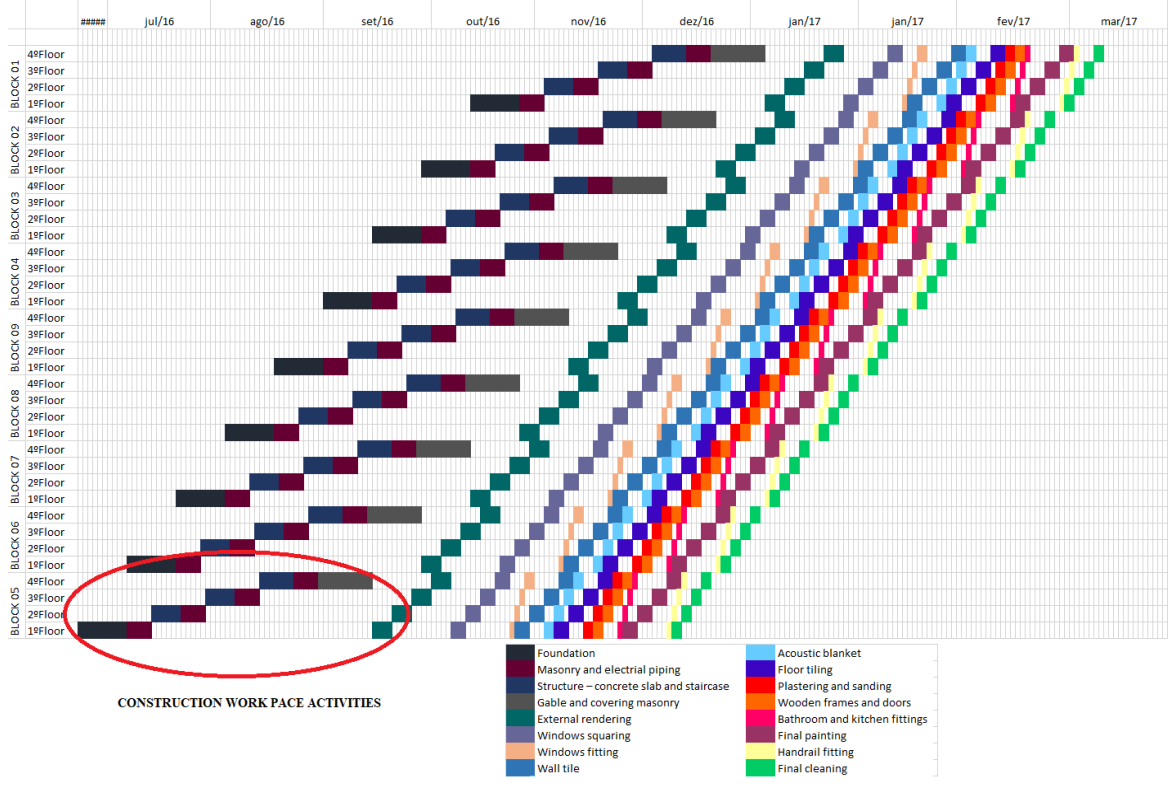

Figure 6. Critical path activities LOB.

The line of balance is an essentially graphical planning method based on a basic unit of repetition. This method is based on the fact that all the construction work has a natural pace and any unbalance results in losses of resources and time. The LOB diagram presents the activities in space (repetition units) and time (months, weeks, days). The behavior of the resulting lines indicates the construction work pace.

The line of balance identified the foundation as the main activity for the construction work to be executed on time. This activity involved a single team for all nine apartment blocks. After it is finished, masonry work begins followed by slab structure and staircases. Such activities account for approximately $68 \%$ of the time required to complete the work, representing a large portion of the schedule.

The line of balance determined the histogram of work teams on-site for the critical path activities (Figure 7) and thus verified the number of work teams needed to maintain the construction pace.

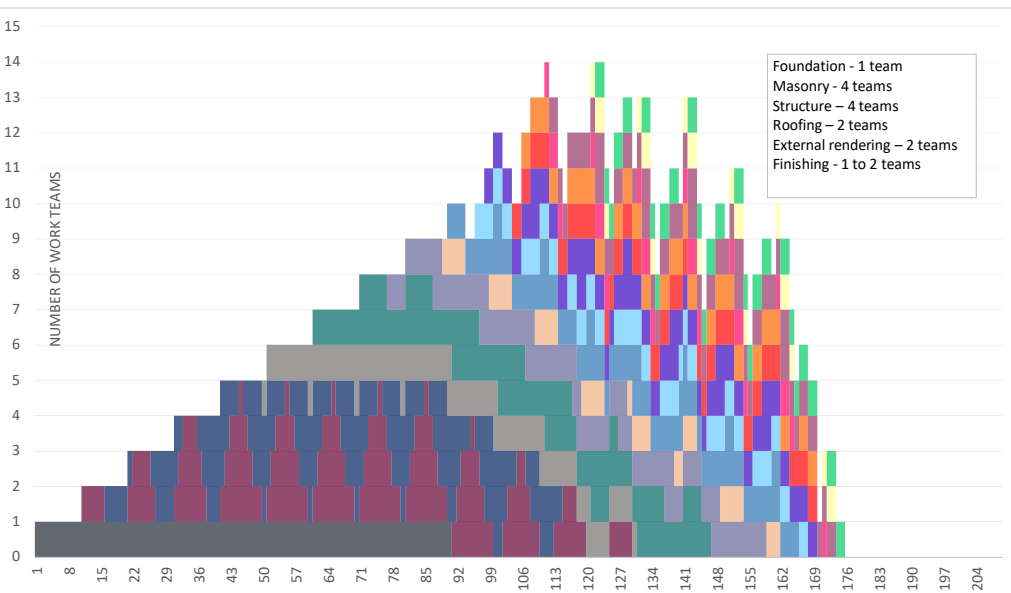

Figure 7. Teams histogram for critical path activities. 
A histogram is a graphical resource distribution representation throughout the schedule (for the workforce), which is a tool for quantitative data analysis and representation grouped into frequency classes that recognize form, the central point and data variation distribution.

From the histogram, it was identified a large number of work teams on-site at masonry completion and starting of finishing work stages. There were also several jobs (and consequently work teams) to be executed simultaneously, which created conflicts making accessibility within the construction site difficult.

By analyzing each schedule stage, the main inputs and equipment to be used over time, their sizes, positioning and length of stay on the site were verified, allowing for the site schedule.

The combined use of the long-term schedule with the construction site schedule aims to list the installation items needed during the work, establishing their assembling dates and length of stay. MS-Project software was used to develop the site schedule, divided into three main categories: site installations, equipment and one-off events.

For the site installations, all provisional installations required for work performance were listed, such as communal areas and material storage structures. Installation and removal periods for each structure and, at times, the positioning change date were defined.

The allocation of the installations was set to remain stationary for as long as possible.

The communal area and warehouse installations (ambulatory, master's room, warehouse, tooling, bagging and materials storage rooms, engineering room, materials warehouse, administration office, bathrooms for administrative personnel and workers, changing room, canteen and storage room for contractors) were positioned to remain stationary until the construction work completion. At the final stage, areas such as the built apartments and party hall, as well as chemical toilets were to be used by the workers.

For installations, such as wood, waste, pipes, and ironworks storage rooms, concrete mixer station, and gravel and sand station were centrally positioned at the site to reduce the distance from the storage site to the application one. However, this storage area had to be shifted due to the paving stage done after the structure job. Such shifting was intended to avoid jeopardising the work development.

The ironworks, carpentry station and block storage area installations were disassembled after completion of the structure. The iron framework, carpentry and masonry work to be done after this period are considered minor, not needing a dedicated storage area.

The length of stay for the equipment used on the construction work was linked to the activity established in the long-term schedule.

One-off events, such as unloading of materials, were listed due to their relevance to the construction work logistics. Some materials are usually delivered in bulk, needing planning as to their unloading and storage location. So, these events had to be related to check for possible interferences in the construction work. Such events are specific to each work. Their relevance is directly linked to delivery logistics, work size, storage space, unloading volume, and transportation equipment.

The construction worksite was a large one with the buildings placed next to one another. For shifting and vertical and horizontal transportation of materials, a telescopic handler was used mainly for the vertical and horizontal transportation of forms, props, steel, mortar and structure boxes and roof tiles. The masonry blocks were hoisted 
directly onto the concrete slab structure by a crane truck provided by the contractor. Besides these materials, the handler also aided on the loading of ceramic tiles, mortar and other palletized materials.

To analyze the equipment's capacity on serving the construction work, the handler's cycle time for material transportation during a critical situation was checked. A $100 \mathrm{~m}$ transport distance was considered for the equipment to move over between the storage area and the site of use. Thus, the equipment's ability to, in the worst-case scenario, shift the material may be verified, as shown in Table 1.

Table 1 showed that the handler required, in the worst-case scenario, $524 \mathrm{~min}$ (8.73 hours) to accomplish all the tasks at the construction work. This showed the equipment's ability to support the construction work since its time was 528 min ( 8.8 hours). The handler was adequate to attend the enterprise, despite the large size of the site. The equipment had frontal access to all the apartment blocks and all the main storage points on the site.

Table 1. Time of telescopic handler use during a critical situation.

\begin{tabular}{|c|c|c|c|c|}
\hline $\begin{array}{l}\text { MATERIAL TO BE } \\
\text { TRANSPORTED }\end{array}$ & CYCLE TIME & $\begin{array}{l}\text { NUMBER OF } \\
\text { TRIPS }\end{array}$ & $\begin{array}{l}\text { NUMBER OF } \\
\text { TEAMS TO BE } \\
\text { SERVED }\end{array}$ & $\begin{array}{l}\text { TOTAL } \\
\text { NEEDED TIME }\end{array}$ \\
\hline \multicolumn{5}{|l|}{ Form: } \\
\hline Wood & $9 \min$ & 2 & 4 & $72 \min$ \\
\hline Props & $9 \min$ & 2 & 4 & $72 \min$ \\
\hline \multicolumn{5}{|l|}{ Framing: } \\
\hline Iron & $12 \min$ & 3 & 4 & $144 \min$ \\
\hline \multicolumn{5}{|l|}{ Rendering: } \\
\hline Boxes & $10 \min$ & 5 & 2 & $100 \min$ \\
\hline \multicolumn{5}{|l|}{ Roofing: } \\
\hline Trellis & $12 \min$ & 3 & 1 & $36 \min$ \\
\hline Ceramic roof tiles & $10 \min$ & 10 & 1 & $100 \mathrm{~min}$ \\
\hline
\end{tabular}

TOTAL $=524 \mathrm{~min}$.

The handler's on-site stay was foreseen until the final roofing completion, which allowed the storage of most materials inside the built apartments, as near to their application as possible. Thus, after removing the equipment from the site, column winches were used for vertical transportation. On top of each concrete slab, the shifting of blocks was done using a dedicated palletized-material horizontal transportation trolley. The construction work used four pallet trolleys to tend to the four masonry teams planned for the peak period. To avoid the handler overuse, the construction site also used four-wheel-trolleys to shift lighter materials.

For unloading logistics, traffic of large trucks on concreting days was avoided since a concrete mixer truck, a concrete pump and a telescopic handler would be on-site, which could cause traffic congestion, increasing the risk of accidents on-site. Thus, the transportation of large quantities of materials such as bathroom and kitchen fittings, floor and wall tiles, windows and doors by open-body trucks have been scheduled so as not to affect the construction work, avoiding congestion risks.

The provisional installations were sized to accommodate the maximum number of workers, avoiding any need for changes. It is worth mentioning that this approach was only feasible due to the construction site's ample physical space, otherwise, alternatives such as shift work would have been made necessary. The maximum number of workers 
was estimated based on the stage with the largest number of activities performed simultaneously, accounting for the size of each work team, as shown in Table 2.

Table 2. Maximum number of workers on-site.

\begin{tabular}{lccc}
\hline \multicolumn{1}{c}{ TASKS } & $\begin{array}{c}\text { NUMBER } \\
\text { OF } \\
\text { TEAMS }\end{array}$ & TEAM COMPOSITION & $\begin{array}{c}\text { TOTAL NUMBER } \\
\text { OF WORKERS }\end{array}$ \\
\hline MASONRY & 4 & $\begin{array}{c}\text { 4 BRICKLAYERS + 1 } \\
\text { BRICKLAYER'S MATE }\end{array}$ & 20 \\
\hline CONCRETE SLAB & 4 & 3 CARPENTERS + 2 FITTERS & 20 \\
\hline FOUNDATION & 1 & 1 CARPENTER + 1 FITTER + & 3 \\
\hline ELECTRICAL & 1 & $\begin{array}{c}\text { 1 ELETE } \\
\text { 1 ASSISTANT }\end{array}$ & 3 \\
\hline HYDRAULICS & 1 & 3 PLUMBERS & 3 \\
\hline $\begin{array}{l}\text { EXTERNAL } \\
\text { RENDERING }\end{array}$ & 2 & 3 BUILDERS + 1 BRICKLAYER'S & 8 \\
\hline $\begin{array}{l}\text { INTERNAL } \\
\text { RENDERING }\end{array}$ & 2 & 3 BUILDERS + 1 BRICKLAYER'S \\
\hline CERAMICS & 2 & 1 BUIDER + 1 ASSISTANT & 8 \\
\hline
\end{tabular}

TOTAL $=69$ WORKERS.

Based on the defined quantity, a two-storey structure with $48 \mathrm{~m}^{2}$ on each floor with B.W.C.s and a changing room downstairs and a 72-people capacity canteen upstairs were built. The positioning and sizing of ambulatory, master's room, storeroom, tooling, bagging and material storage rooms, engineering room, administrative office and bathrooms were determined.

The material storage and workstation areas positioning were also defined, as well as their repositioning along with the schedule. Such areas were positioned centrally to the construction work, however, they were relocated due to paving. Despite the inconvenience of relocation these temporary structures, after paving, they were kept at such areas to reduce the materials transporting distance to the apartment blocks (49 $\mathrm{m}$ ) On the other hand, when these structures were moved either to the front or to the back area of the construction site (not interfering with the paving), the average transportation distance increased to $94.5 \mathrm{~m}$, adding to productivity losses.

Annex I presents the enterprise implementation sketch taking into account the construction site interference. The sketch showed the communal facilities area, the equipment area that affected the provisional structures positioning, and their interpositions.

Once the construction work planning and the items needed in the site were determined, the site layout 4D BIM model was developed.

Phase one of the project defined the 3D model. The constructions, plot of land and the main infrastructure components were modelled. The architectural, structural, installations and levelling 2-D projects developed by the construction company were used as a reference. The model was performed using Autodesk Revit software.

A project parameter was established for each modelled element, linking the object to a specific construction schedule item. The same occurred for the construction site elements with communal areas, material centers or equipment related to the construction site schedule. Figure 8 shows the link established between a 3D model item and the MS-Project schedule. For the object representing the pile driving equipment executing the elevated water reservoir foundation, a new data parameter 
named EDT was created, within the 3D model properties, with the same correspondence in the schedule using MS-Project software.

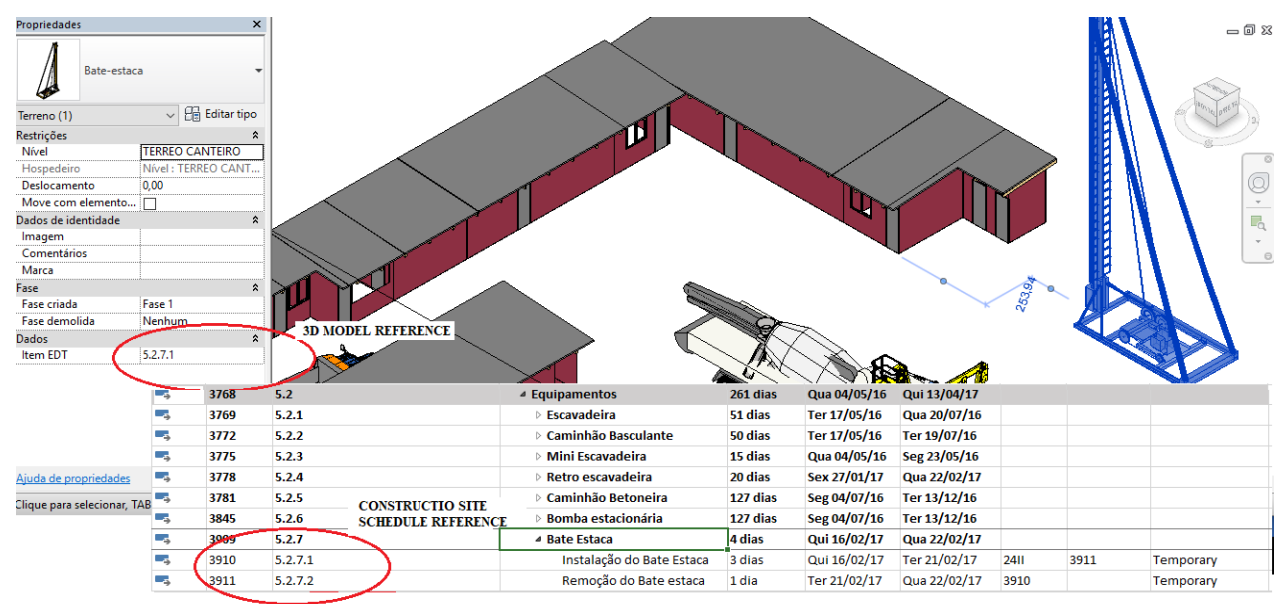

Figure 8. 3D and project schedule correlation.

Various 3D construction site model elements were imported from Sketchup software, such as trucks, diggers, pile drivers and concrete pumps. These objects are not parameterized, having solely a representative purpose. Even so, they were relevant for the project, since their visualization and positioning in physical space allows for space occupation and accessibility conflict analyses.

The 3D models and the schedule were imported into Navisworks software, which links the 3D model parameterized objects to the time factor, creating a truly dynamic site planning.

Once the project was developed, the whole structure of the construction work development may be evaluated, checking the spatial layout of all objects, equipment, materials and communal areas necessary to support the enterprise's schedule.

Figures 9 to 14, obtained from the Navisworks software, refer to the product from the dynamic construction site planning development.

During the first few months of the construction work (Figure 9), the communal areas such as B.W.C.s canteen, changing room, offices, storerooms and warehouses had already been positioned in a pre-set area so as not to jeopardize the work development. The steel material, pipes, wood, cutting and bending, and sawmill stations were centrally positioned in the site to reduce transport distance. At this stage, backhoe loaders and dump trucks had also been positioned for earthwork.

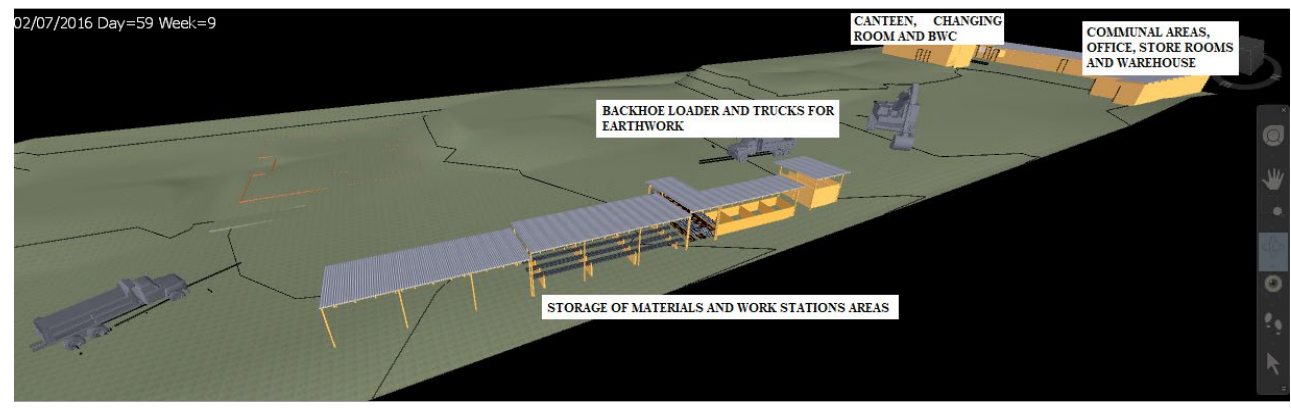

Figure 9. Navisworks software image showing the construction site structure in the initial months of construction work. 
Storage locations of roof structure trellis, structural blocks and concrete mixer station were determined during the critical path main tasks execution (foundation, masonry and structure) (Figure 10). The telescopic handler's main function was to transport steel, wood and props both vertically and horizontally. At this stage, for the slabs concreting, the concrete mixer trucks and concrete pumps traffic was heavy. Figure 9 also shows the periphery protection screens representation installed on the concrete slab.

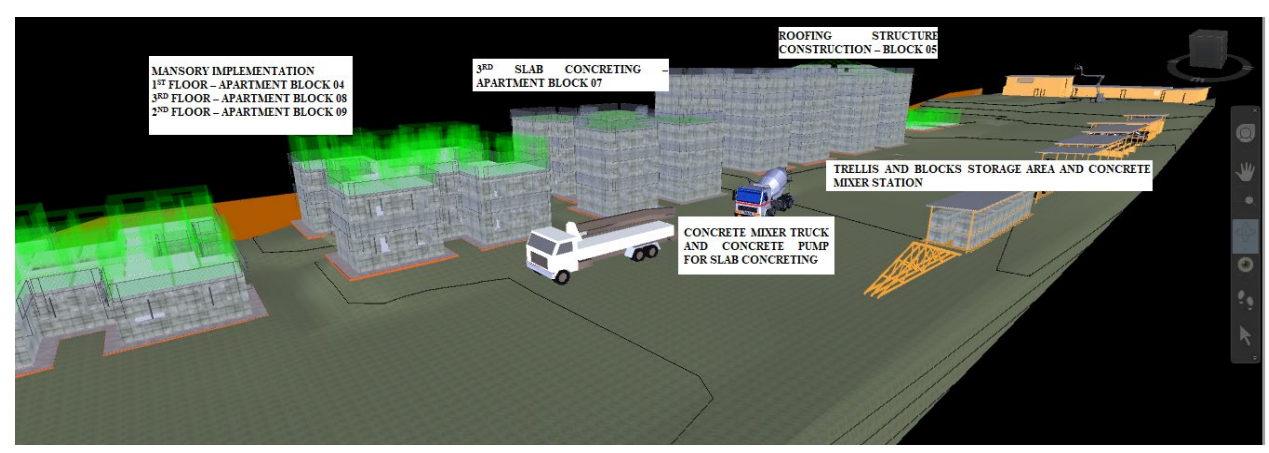

Figure 10. Navisworks software image showing the construction site layout at the critical path main tasks stage.

At the finishing stage, the critical path main tasks (masonry and structure) and rendering were initiated, establishing the areas to place the mortar mixing boxes for internal and external rendering and the façade scaffolding for external rendering. The telescopic handler was still on-site to transport roofing and tile structures, floor tiles, mortar and plastering (Figure 11).

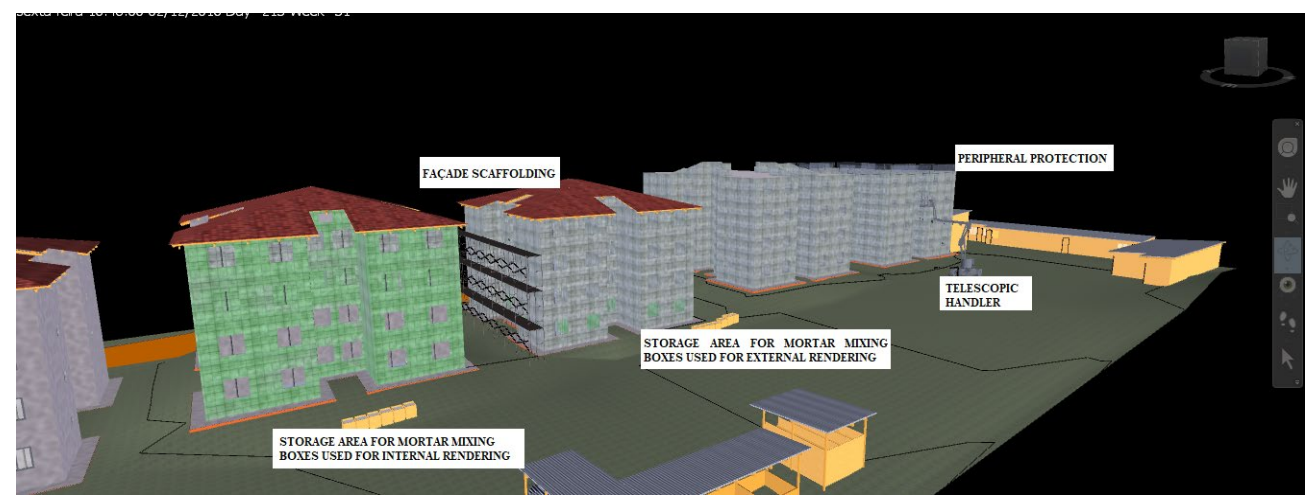

Figure 11. Navisworks software image showing the construction site layout at the final stage of critical path main tasks.

At the time of installing the pile driver to execute the elevated water reservoir foundation, the masonry, structure and roofing work had been completed and the telescopic handler was removed from the construction site. The communal areas and material centers remained in the same positions (Figure 12). 


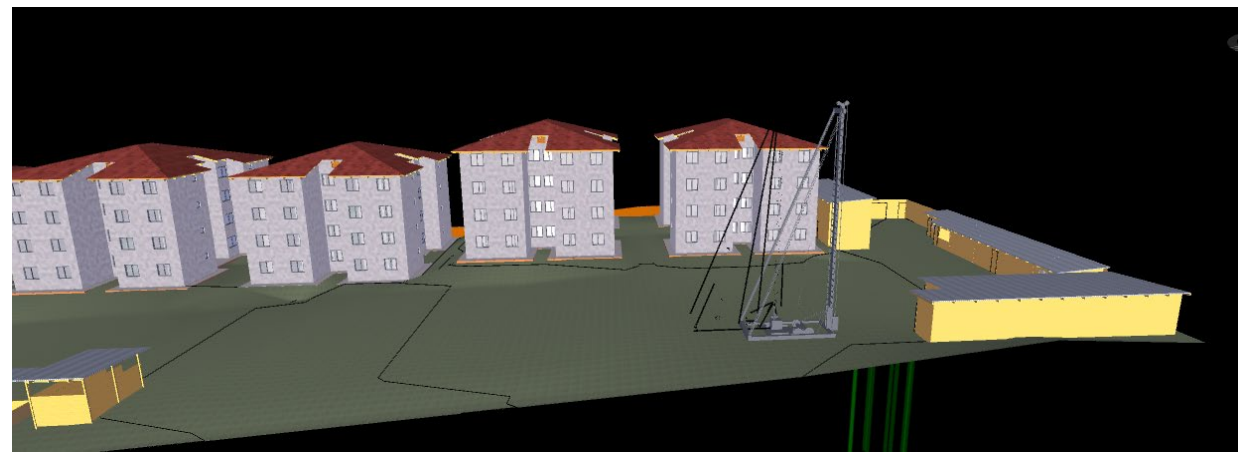

Figure 12. Navisworks software image showing the pile driver installation for elevated water reservoir foundation.

In the provisional structures demobilising stage, the workstations were removed from the construction work. The steel, pipe, wood and concrete mixer stations were repositioned at the back of the construction site to allow for the parking lot paving (Figure 13). At this stage, the external rendering and façade texture work had already finished and the finishing jobs such as electrical cabling, painting and fittings installation were in progress.

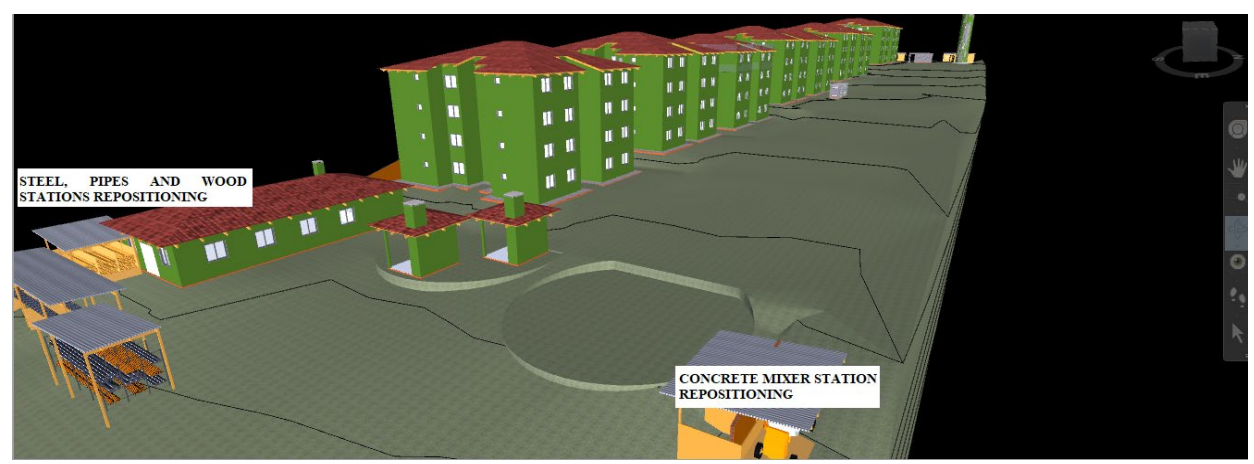

Figure 13. Navisworks software image showing the construction site layout setting with the material centers and concrete mixer station repositioning.

Figure 14 presents the completed project with all provisional facilities demobilized.

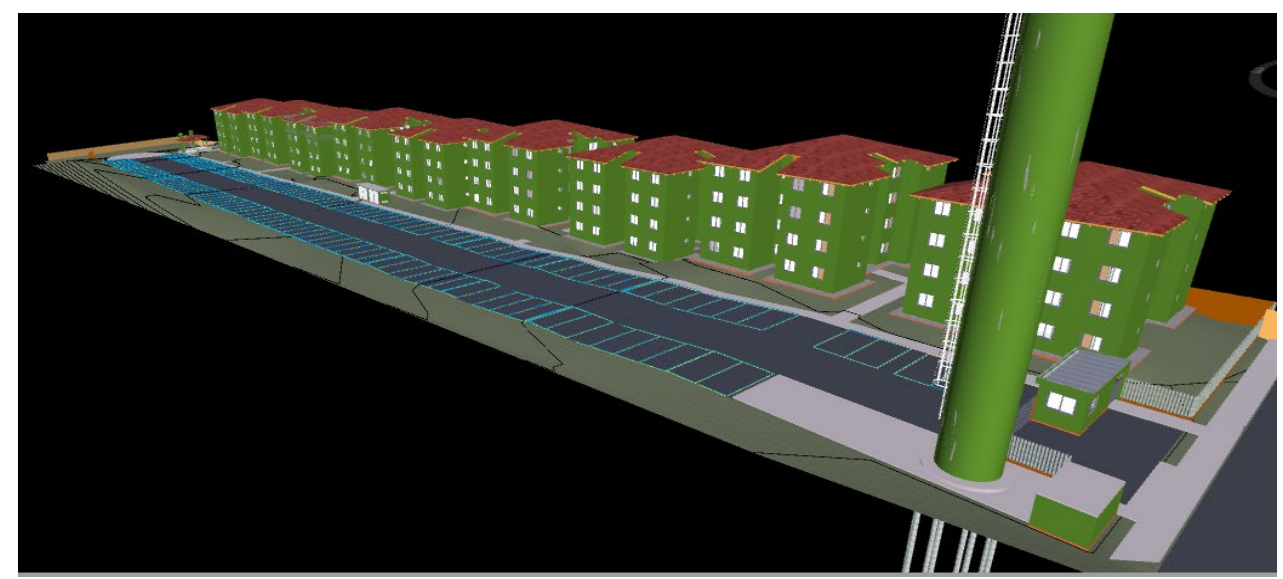

Figure 14. Navisworks software image showing provisional facilities demobilization. 


\subsection{Artifact evaluation}

The model was applied on-site from January to March 2017. Although the period for its evaluation was restricted, inferences such as specific characteristics, applicability and difficulties for use were plausible.

At this stage, the foundation, masonry and concrete slab jobs were already completed and the roofing and internal and external rendering jobs were on their final process. Windows, floor and wall tiles fitting, façade texture, plastering and sanding of apartments were in progress, as well as party hall and barbecue kiosks construction. In this stage, doors fitting, wiring, cabling, bathroom and kitchen fittings installation and elevated water reservoir construction were initiated.

At this stage of the schedule, the materials centers and work stations were centrally located on the construction site as per planning. Equipment such as façade scaffolding remained on-site. The apartment blocks periphery protection screens and telescopic handler were removed and a column winch for vertical transportation of materials to apartment block 01 was installed, as well as positioning a pile driver to execute the elevated water reservoir foundation.

It was verified on the construction site that its configuration and the equipment to aid on the construction processes were adequate and coherent to the planning. However, one-off issues eventually diverged from the plan.

A part of the administrative office was positioned on top of the parking lot. During the building alignment, this structure was repositioned to allow for the parking lot paving.

In the site planning, the facilities of the communal area were defined not to be repositioned, so as not to incur additional costs. Another one-off issue was the elevated water reservoir foundation construction. When placing the pile axes, it was noticed that they crossed over to the parking lot. Although the water reservoir had a $3.40 \mathrm{~m}$ diameter, its foundation had a $5.50 \mathrm{~m}$ diameter, crossing $50 \mathrm{~cm}$ over the parking lot, which would not be a disruption if this area was not a city council easement, since a local municipality tunnel passes through this area. Therefore, the project had to be changed so that the foundation would fit in a $5 \mathrm{~m}$ space, being rescheduled causing a delay.

When the construction site project model was developed, the elevated water reservoir foundation had not yet been designed, so an estimated foundation was specified to be updated later. Had this process occurred at the time of updating the elevated water reservoir foundation structure, such inconsistency could have been observed and the schedule could have been kept as planned.

The model in the construction work was visually useful to analyze the positioning of the equipment, have their used time checked on-site and verify accessibility issues.

During the pile driver installation for the elevated water reservoir construction, simulations to allow the transit of floor-tile loaded trucks were performed. Such simulations support decision making that directly reflects on the performance schedule.

The model also verified any possible conflicts between the scaffolding installation and the communal areas (canteen, B.W.C.s and changing room). The communal areas positioning should foresee the scaffolding positioning for apartment block 01 façade rendering, thus avoiding interference between the structures, as desired in the construction site project.

In addition to the issues pointed out, the construction site project using 4D BIM modeling assisted on equipment removal planning from the construction site, such as façade scaffolding and periphery protection screens. During this model evaluation period, the periphery protection screens were removed by the supplier. The protection screens were no longer in use, however, the supplier had not yet removed them due to 
the year-end recess. Equipment removal schedule is essential to avoid them taking unnecessary space or adding additional costs.

It is assumed that the project model for the construction site development has truly assisted to better visualize the equipment length of stay on the construction site and helping in the inferences such as installation and demobilization scheduling, time use analysis, as well as cost estimates.

\section{Conclusions}

The study presented a 4D BIM modeling process for construction site layout planning considering its dynamic characteristic.

A dynamic site model takes into account the length of stay needed for each equipment or installation on-site. A specific and detailed project is required for its development.

The construction site project is directly linked to work planning. In this study, the $4 D$ BIM modeling site planning process was entirely based on planning information and executable management of the enterprise.

From the process analysis and understanding used in the construction site planning development with quite peculiar situations such as confined space, access difficulty and site limitations. It allowed for inferences to be made regarding its relevance and application and, thus, propose processes for a dynamic site layout planning development in a new context.

The study assisted in determining a suitable and viable process for dynamic site layout planning, establishing the necessary steps and the correct time at which they should be considered and implemented.

The use of 4D BIM modeling proved suitable to solve construction sites' dynamic issue since it linked each project item to the time factor. This way, the project may show the actual length of stay for each equipment or installation in the construction site.

During the 4D BIM modeling use, the relevance of analyses established by visualizing of the spatial layout, supporting decision making due to its simulation capacity was noted. The demobilization of a structure and its repositioning is labor intense increasing costs. On the other hand, the demobilization of certain structures at a specific time during the construction work brings gains due to a travelling distance reduction within the site. In this sense, the 4D BIM model may assist in analysis and definition of these situations, identifying conflicts and accessibility issues during the construction works progress.

The construction site model developed proved efficient, with relevant information that assisted the construction work management during its schedule, improving production, quality and safety.

The 4D BIM model implementation process for dynamic site planning proved suitable. Nonetheless, proper training must be given to the construction work teams to use the model. Data feeding and updating must be done by the construction team, otherwise, its dynamic characteristic may be lost.

It is worth mentioning the utmost importance of model updating, as well as the construction work planning that must be constantly reviewed and updated. The same applies to the construction site planning due to their interconnection. Model inconsistencies with the real construction work occur having the same function as a static project, should this procedure not be performed. 


\section{References}

Andayesh, M., \& Sadeghpour, F. (2013). Dynamic site layout planning through minimization of total potential energy. Automation in Construction, 31, 92-102. http://dx.doi.org/10.1016/j.autcon.2012.11.039.

Bataglin, F. S., Viana, D. D., Formoso, C. T., \& Bulhões, I. R. (2018). BIM 4D aplicado à gestão logística: implementação na montagem de sistemas pré-fabricados de concreto Engineerto-order. Ambiente Construído, 18(1), 173-192. http://dx.doi.org/10.1590/s167886212018000100215.

Cheng, M., \& Chang, N. (2019). Dynamic construction material layout planning optimization model by integrating 4D BIM. Engineering with Computers, 35(2), 703-720. http://dx.doi.org/10.1007/s00366-018-0628-0.

Dresch, A., Lacerda, D. P., \& Antunes, J. A. V., Jr. (2015). Design Science research: Método de pesquisa para avanço da ciência e tecnologia (181 p.). São Paulo: Bookman. http://dx.doi.org/10.1007/978-3-319-07374-3.

El-Rayes, K., \& Khalafallah, A. (2005). Trade-off between safety and cost in planning construction site layouts. Journal of Construction Engineering and Management, 131(11), 1186-1195. http://dx.doi.org/10.1061/(ASCE)0733-9364(2005)131:11(1186).

Gehbauer, F. (2002). Planejamento e gestão de obras ( $2^{\mathrm{a}}$ ed.). Curitiba: CEFET-PR.

Hevner, A. R., March, S. T., Park, J., \& Ram, S. (2004). Design science in information systems research. MIS quarterly, 75-105.

Kumar, S. S. (2015). A BIM-based framework for site layout optimization and material logistics planning on congested construction sites (Thesis). Hong Kong University of Science and Technology, Hong Kong. http://dx.doi.org/10.14711/thesis-b1514767.

Kumar, S. S., \& Cheng, J. C. P. (2015). A BIM-based automated site layout planning framework for congested construction sites. Automation in Construction, 59, 24-37. http://dx.doi.org/10.1016/j.autcon.2015.07.008.

Kymmel, W. (2008). Building information modeling: planning and managing construction projects with $4 D C A D$ and simulations. New York: MCGraw-Hill.

Li, H., \& Love, P. E. D. (1998). Site-level facilities layout using genetic algorithms. Journal of Computing in Civil Engineering, 12(4), 227-231. http://dx.doi.org/10.1061/(ASCE)0887-3801(1998)12:4(227).

Maia, A. C., \& Souza, U. E. L. (2003). Método para conceber o arranjo físico dos elementos do canteiro de obras de edifícios: fase criativa. São Paulo: EPUSP.

Martins, G. P., \& Laugeni, P. F. (2005). Administração da produção (2a ed., 562 p.). São Paulo: Saraiva.

Marzouk, M., \& Abubakr, A. (2016). Decision support for tower crane selection with building information models and genetic algorithms. Automation in Construction, 61, 1-15. http://dx.doi.org/10.1016/j.autcon.2015.09.008.

Sadeghpour, F., \& Andayesh, M. (2015). The constructs of site layout modeling: an overview. Canadian Journal of Civil Engineering, 42(3), 199-212. http://dx.doi.org/10.1139/cjce-2014-0303.

Saurin, T. A., \& Formoso, C. T. (2000). Análise das práticas de planejamento de layout e logística em um conjunto de canteiros de obra no Rio Grande do Sul. Produto \& Produção, 4, 14-25.

Simon, H. A. (1996). The Science of Artificial (3rd ed.). Cambridge: MIT Press.

Souza, U. E. L. (2000). Projeto e implantação do canteiro. São Paulo: O Nome da Rosa Ltda.

Sulankivi, K., Makela, T., \& Kiviniemi, M. (2009). BIM-based site layout and safety planning. In Proceedings of the First International Conference on Improving Construction and Use Through Integrated Design Solutions: CIB IDS 2009. Finland: VTT Technical Research Centre of Finland.

Tommelein, I. D., Levitt, R. E., \& Hayes-Roth, B. (1992). SightPlan model for site layout. Journal of Construction Engineering and Management, 118(4), 749-766.

http://dx.doi.org/10.1061/(ASCE)0733-9364(1992)118:4(749). 
Whitlock, K., Abanda, F. H., Manjia, M. B., Pettang, C., \& Nkeng, G. E. (2018). BIM for construction site logistics management. Journal of Engineering, Project, and Production Management, 8(1), 47-55. http://dx.doi.org/10.32738/JEPPM.201801.0006.

Yeh, I.-C. (1995). Construction-site layout using annealed neural network. Journal of Computing in Civil Engineering, 9(3), 201-208. http://dx.doi.org/10.1061/(ASCE)0887-3801(1995)9:3(201).

Yu, Q., Li, K., \& Luo, H. (2016). A BIM-based dynamic model for site material supply. Procedia Engineering, 164, 526-533. http://dx.doi.org/10.1016/j.proeng.2016.11.654.

Zolfagharian, S., \& Irizarry, J. (2014). Current trends in construction site layout planning. In Construction Research Congress 2014 (pp. 1723-1732). Reston: American Society of Civil Engineers. http://dx.doi.org/10.1061/9780784413517.176.

Zouein, P., \& Tommelein, I. D. (1999). Dynamic layout planning using a hybrid incremental solution method. Journal of Construction Engineering and Management, 125(6), 400-408. http://dx.doi.org/10.1061/(ASCE)0733-9364(1999)125:6(400). 
Annex I. Enterprise implementation sketch influenced by the construction site.

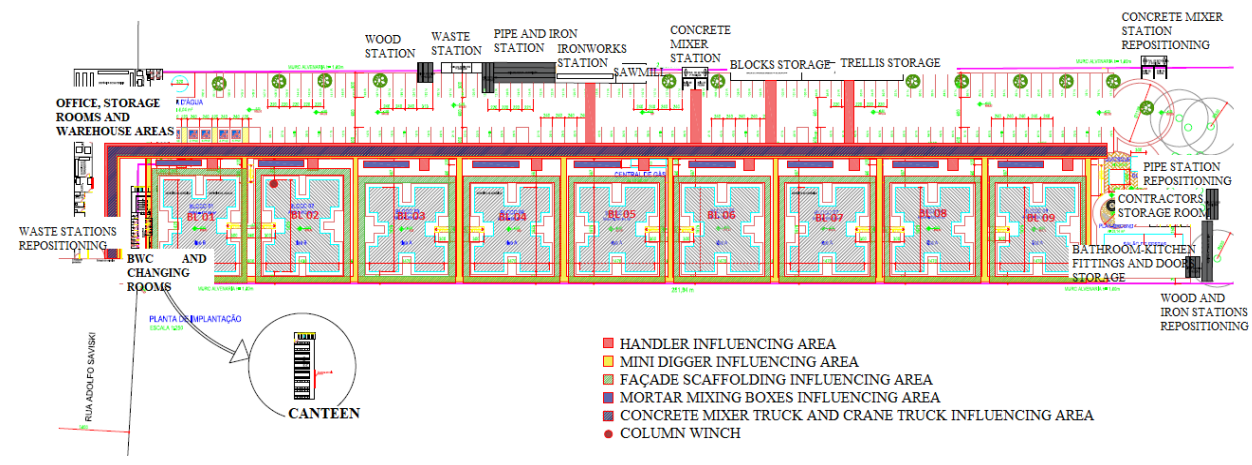

